organizing the public activity of the authorities regarding compliance with the law in limiting access to classified, confidential and official information are considered. A clear list of reasons for attributing information to the category of restricted persons is defined. It also examines the essence of the legislature's basic democratic approach whereby any possibility of restricting access to information can arise only when the restriction is made solely in the interests of national security, public order or the protection of the rights of others; disclosure of information may cause significant harm to those interests; the harm of disclosing such information outweighs the public interest in obtaining it. It is emphasized that the law indicates the mandatory presence of a set of these features.

In addition, the paper concludes that even the indisputable recognition of certain information as official or even secret or confidential does not mean that it cannot be provided for use by a specific person. Information cannot be denied only because the relevant type of information is included in the list of information that constitutes business information. In the case of public need for this information, they may also be made publicly available: in each case where a particular information is given the status of "official use" of the information manager, the so-called "three-part test" must be applied. The content of such testing and its specific manifestations are analyzed. The refusal to satisfy the request for information must be reasoned, that is, the refusal of the information manager is obliged to justify the existence of grounds for restriction in access, which constitute the content of the "three-part test". The following are indications of good and fair practice in the commentary field applied by the European Court of Human Rights.

Key words: open access, public information, confidential information.

DOI: $10.36695 / 2219-5521.2 .2019 .23$

УДК 347.672

\title{
М.O. МИХАЙЛІВ
}

Марія Омелянівна Михайлів, кандидат юридичних наук, доцент, доцент Львівського національного університету імені Івана Франка*

ORCID: 0000-0002-5007-7810

\section{УНІФІКАЦІЯ КОЛІЗІЙНИХ НОРМ У СФЕРІ СПАДКОВИХ ВІДНОСИН}

Постановка проблеми. Найбільш дієвим інструментом правового регулювання спадкових відносин у міжнародному приватному праві, окрім інших видів джерел, $є$ міжнародні договори. На сьогодні міжнародні договори залишаються чи не єдиним в Україні найбільш ефективним способом уніфікації норм у сфері спадкування, що допомагає усунути розбіжності як між матеріальними, так і між колізійними нормами держав у даній сфері.

Аналіз останніх досліджень і публікацій з даної теми. Питанням уніфікації норм у сфері спадкових відносин в міжнародному приватному праві приділяли увагу ряд українських та іноземних вчених, таких, наприклад, як: М.І. Браун, Г.В. Галущенко, І.Г. Гетьман-Павлова, Н.Г. Вілкова, Г.К. Дмитрієва, А.С. Довгерт, О.О. Кармаза, В.І. Кисіль, Л.А. Лунц, І.Г. Медведєв, Н.В. Орлова, А.А. Рубанов, А.А. Степанюк, В.Л. Толстих, С.І. Фурса, С.А. Фурса, А.Г. Хачатурян та ін. Проте в науці ще залишається чимало питань, які потребують дослідження та є актуальними і на сьогодні.

Мета статті. Визначити поняття та правову природу уніфікації в міжнародному приватному праві. Проаналізувати зміст норм міжнародних договорів та визначити місце, яке вони займають серед джерел міжнародного приватного права у врегулюванні відносин міжнародного спадкування. Виокремити проблеми колізійного регулювання міжнародних спадкових відносин в міжнародних договорах та запропонувати шляхи їх вирішення.

Виклад основного матеріалу. Спадкові відносини, ускладнені іноземним елементом, за своїм характером є складними, оскільки завжди пов'язані із правопорядками двох або більше держав. А це, в свою чергу, призводить до появи проблем їх належного правового регулювання.

Суб'єкти спадкових відносин, як правило, стикаються з труднощами, пов'язаними із вибором матеріального права, яке має застосовуватися до правовідносин у сфері спадкування. Саме колізійні норми і $є$ тим інструментом, який має своїм завданням визначити, право якої держави буде застосовним до приватноправових відносин з іноземним елементом. Проте за змістом колізійні норми у сфері спадкування іноземних держав різняться, або ж вони взагалі відсутні, а це, в свою чергу, вказує на потребу в уніфікації таких норм на міжнародному рівні.

Відсутність єдиних колізійних норм спадкування та збігу з колізійними нормами інших правопорядків, на думку М. Брауна, може призвести до того, що особа втратить право спадкувати. Поки не існує єдиної системи колізійного права, доля кожних правовідносин піддається випадковості. Різноманіття колізійних норм завдає удару сучасній правосвідомості ${ }^{1}$.

Ідея уніфікації колізійних норм зародилася ще наприкінці XIX ст. як теорія універсалістів. Проте і на сьогодні втілити цей задум не вдалося. Неоднозначні погляди вчених можемо спостерігати і щодо питань,

(C) М.О. Михайлів, 2019

* Mariya Mykhailiv, Ph.D. in Law, Associate professor, Associate professor of Ivan Franko of Lviv National University 
пов’язаних із доцільністю проведення уніфікації колізійних норм чи матеріально-правових. Вважаємо, що на практиці існує потреба як в уніфікації колізійних так і матеріально правових норм у сфері спадкування, у зв'язку із чим надавати перевагу одному із видів такої уніфікації недоцільно. Проте провести уніфікацію матеріальних норм у сфері спадкування, на відміну від уніфікації колізійних норм, є процесом досить складним, а в більшості випадках і неможливим.

На думку О.О. Кармази, розбіжності між правом окремих держав у галузі спадкування настільки великі, що уніфікація матеріально-правових норм на міжнародному рівні є недосяжною. Нині можлива лише уніфікація окремих норм або уніфікація на регіональному рівні - між державами з однаковими правовими системами‥ кації.

В доктрині існують різні підходи до визначення поняття «уніфікація», її правової природи та класифі-

Загалом в науковій літературі склалося три підходи до розуміння уніфікації: 1) визначення уніфікації розкривається через вчинення сукупності дій та застосування засобів, які становлять зміст процесу уніфікації, проте не зазначається мета, заради якої вона здійснюється (А.Л. Маковський, А.С. Мамулян, С.Ю. Кашкіна); 2) визначення уніфікації, як правило, зводиться до наслідку на який спрямований процес уніфікації (А.Г. Хачатурян, Г.С. Фединяк); 3) визначення уніфікації в своєму змісті поєднує як зміст так і спрямованість такого процесу (А.С. Довгерт, Г.К. Дмитрієва, Н.Г. Вілкова, Л.Г. Варшаломідзе). Вважаємо, що для кращого розуміння поняття та правової природи уніфікації найбільш вдалим видається третій підхід.

Уніфікація в галузі міжнародного приватного права, на думку Г.К. Дмитрієвої, це співпраця держав, спрямована на створення, зміну чи зупинення однакових правових норм у внутрішньому праві певного кола держав ${ }^{3}$. А.С. Довгерт уніфікацію визначає як правотворчий процес, спрямований на створення правових норм для декількох національних правових систем, який є засобом забезпечення однаковості національноправових норм (колізійних і матеріальних), що регулюють цивільно-правові відносини 3 міжнародним елементом ${ }^{4}$.

Отже, міжнародна приватноправова уніфікація як правотворчий процес здійснюється в спосіб прийняття міжнародних договорів, проте завершеною вважається з моменту імплементації таких норм договірними державами - учасницями.

Загалом міжнародна уніфікація норм у сфері спадкування може здійснюватися в різний спосіб. У зв'язку із чим виділяють багатосторонню, регіональну та двосторонню уніфікацію у сфері спадкових відносин. За видом норм, які містяться в уніфікованих актах, можемо виділити: уніфікацію колізійних норм у сфері спадкування; уніфікацію матеріальних норм у сфері спадкування; змішану уніфікацію.

На сьогоднішній день міжнародна уніфікація у сфері спадкування є незначною. На міжнародному рівні було прийнято лише кілька багатосторонніх міжнародних договорів, а саме:

1. Гаазька конвенція про колізії законів стосовно форми спадкових розпоряджень від 5 жовтня 1961 року5. Цим міжнародним договором передбачено широкий вибір колізійних прив'язок. Так, ст. 1 Конвенції передбачає, що заповіт $є$ дійсним стосовно форми, якщо його форма відповідає внутрішньому законодавству держави: де заповідач його склав; громадянства заповідача на момент складення заповіту чи на момент його смерті; постійного місця проживання заповідача на момент складення заповіту чи на момент його смерті; звичайного місця проживання заповідача на момент складення заповіту чи на момент його смерті; настільки, наскільки це стосується нерухомості, - иї місцезнаходження.

Україна приєдналася до Конвенції 17 грудня 2009 р. із трьома застереженнями. Так, відповідно до Конвенції визначення того, чи мав заповідач постійне місце проживання в певному місці, регулюється правом цього місця. При цьому Україна зробила застереження, відповіднодо якого залишила за собою право визначати місце постійного проживання заповідача згідно із законом суду (lex fori). Крім цього, Україна залишила за собою право не визнавати заповіти, вчинені громадянами України в усній формі, окрім тих, які вчинені за виняткових обставин. Для України Конвенція набула чинності 14 травня 2011 року.

2. Вашингтонська конвенція, що передбачає уніфікований закон про міжнародний заповіт від 26 жовтня 1973 року6. Ця конвенція є єдиним прикладом уніфікації матеріальних норм спадкового права, інші конвенції містять уніфіковані колізійні норми щодо спадкування 7 .

Конвенція містить зобов'язання держав-учасниць включити у їх внутрішні законодавства положення, що стосуються типової форми міжнародного заповіту. Заповіт, складений у такій формі, вважається дійсним 3 погляду форми незалежно від місця його складення, місця знаходження майна, громадянства, постійного чи тимчасового місця проживання спадкодавця.

Фактично, «міжнародний заповіт»є формою, розробленою із врахуванням світових законодавств та практики у сфері спадкування. Такий заповіт повинен мати письмову форму, причому не обов'язково, щоб він був написаний самим заповідачем, допускається використання технічних засобів. Якщо особа не здатна скласти заповіт самостійно, це може бути зроблено з їі слів іншою особою. Заповідач у присутності двох свідків і особи, яка має посвідчити заповіт, проголошує, що даний документ є його заповітом, і зміст такого заповіту йому відомий. Ознайомлення свідків та уповноваженої особи зі змістом заповіту не є обов'язковим. Типовий закон встановлює лояльні вимоги до здатності бути свідком, встановлюються вимоги щодо посвідчення заповітів тощо ${ }^{8}$.

3. Конвенція про право, що застосовується до спадкування майна померлих осіб, прийнята у Гаазі 1 серпня 1989 року9. Ця Конвенція визначає право, що застосовується до спадкування майна померлих осіб. 
Конвенція не застосовується щодо визначення: а) форм розпорядження майном після смерті; б) здатності до розпорядження майном після смерті; в) питань, що стосуються спільної власності подружжя; г) майнових прав, інтересів або активів, створених або переданих іншим способом, ніж у спадок, наприклад, у спільній власності з правом на виживання (survival), пенсійних планів, договорів страхування або механізмів аналогічного характеру.

Стаття 3 цієї Конвенції встановлює, що спадкування регулюється правом держави, в якій спадкодавець на момент його смерті мав постійне місце проживання, за умови, що він був громадянином цієї держави. Спадкування також регулюється правом держави, в якій спадкодавець на момент його смерті мав постійне місце проживання, але за умови, що він проживав у цій державі не менше п'яти років, що безпосередньо передували його смерті. Проте у виняткових випадках, якщо в момент його смерті він був явно більш тісно пов’язаний з державою, громадянином якої він був, застосовується право цієї держави. У всіх інших випадках до спадкування застосовуватиметься право держави, громадянином якої був спадкодавець на момент смерті, якщо на цей момент він більш тісно не був пов'язаний з іншою державою.

Конвенція також передбачає можливість спадкодавця обрати (designate) право, яке застосовуватиметься до спадкування усього його майна. Але такий вибір матиме силу лише у разі, якщо на цей момент чи на момент його смерті він був громадянином цієї держави чи мав у ній постійне місце проживання. Такий вибір повинен бути здійснений у формі, що відповідає формальним вимогам щодо розпорядження майном на випадок смерті. Чинність такого вибору визначається за правом обраної (designated) держави. При тому спадкодавець може обрати право однієї чи декількох держав, що регулюють спадкування окремих видів майна.

Таким чином, хоча Конвенція так і не набула чинності, проте є важливим кроком до уніфікації спадкових відносин.

4. Гаазька конвенція про міжнародне управління спадковим майном від 2 жовтня 1973 року. Цією конвенцією передбачено запровадження спеціального сертифікату - «міжнародне посвідчення адміністратора спадщини». Цим документом визначаються повноваження адміністратора щодо управління рухомим майном, яке входить до складу спадщини. Конвенцією також передбачено вимоги, пов'язані із формою такого документа, умови визнання і підстави для відмови у визнанні таких посвідчень. Питання, пов'язані із видачею даного документа, регулюються правом держави звичайного місця проживання спадкодавця.

Проте, на думку В.І. Кисіля, більший успіх мали зусилля щодо уніфікації норм про спадкування на регіональному рівні (Європейські співтовариства, країни Латинської Америки, країни СНД). Однак чи не найбільш дієвим механізмом міжнародно-правового регулювання спадкових відносин сьогодні виступають двосторонні міжнародні договори ${ }^{10}$.

Уніфікація колізійних норм у сфері спадкування в країнах СНД була проведена як на регіональному рівні, шляхом прийняття у Мінську 22 січня 1993 р. Конвенції про правову допомогу та правові відносини у цивільних, сімейних та кримінальних справах ${ }^{11}$ так і шляхом укладення окремими державами двосторонніх міжнародних договорів у сфері надання правової допомоги.

Конвенція про правові відносини і правову допомогу у цивільних, сімейних та кримінальних справах застосовується до тих справ про міжнародне спадкування, які зачіпають правопорядки країн - учасників СНД за умови відсутності між ними відповідного двостороннього договору12.

Питанням спадкування в конвенції присвячений розділ п'ятий, який містить сім статей: принцип рівності; право спадкування; перехід спадщини до держави; заповіт; компетенція у справах про спадщину; компетенція дипломатичного представництва або консульської установи у справах про спадщину; заходи для охорони спадщини.

Принцип рівності, відповідно до конвенції, полягає у тому, що громадяни кожної з Договірних Сторін можуть успадковувати на територіях інших Договірних Сторін майно або права за законом або за заповітом на рівних умовах і в тому ж обсязі, як і громадяни цієї Договірної Сторони.

Конвенція надає перевагу роздільному режиму колізійного регулювання права спадкування майна. Так, зокрема, якщо спадкове майно належить до нерухомого, застосовуватися буде колізійна прив'язка законодавство Договірної Сторони, на території якої знаходиться це майно. Щодо іншого майна - законодавство Договірної Сторони, на території якої спадкоємець мав останнє постійне місце проживання (ст. 45 Конвенції).

Відповідно до ст. 47 Конвенції, здатність особи до складання і скасування заповіту, а також форма заповіту і його скасування визначаються за правом тієї країни, де заповідач мав місце проживання в момент складання акта. Однак заповіт або його скасування не можуть бути визнані недійсними внаслідок недотримання форми, якщо остання задовольняє вимоги права місця його складання. Конвенція також містить важливі положення про компетенцію по справах про спадщину, яка залежить від виду спадкового майна. Так, ст. 48 закріплює положення, що провадження у справах про спадкування рухомого майна компетентні вести установи Договірної Сторони, на території якої мав місце проживання спадкодавець у момент своєї смерті, а щодо нерухомого майна - установи Договірної Сторони, на території якої знаходиться майно. Стаття 49 закріплює положення про компетенцію дипломатичного представництва та консульської установи у справах про спадщину. При цьому дипломатичним представництвам або консульським установам не потрібно спеціального доручення, щоб представляти в установах інших Договірних Сторін громадян своєї держави, якщо вони відсутні або не призначили представника.

Чинними для України двосторонніми міжнародними договорами про правову допомогу є договори 3 двадцятьма державами. 
За часів незалежності Україна уклала двосторонні договори про правову допомогу в цивільних та сімейних справах із Китайською Народною Республікою (1992 р.), Литвою (1993р.), Польщею (1993р.), Грузією (1995 р.), Латвією (1995 р.), Молдовою (1995 р.), Естонією (1996 р.), Македонією (2000р.), Румунією (2002 р.), Кіпром (2005 р.) та іншими державами. Чинними для України залишаються договори, укладені між Радянським Союзом та Албанією (1958 р.), Болгарією (1975 р.), В’єтнамом (1981р.), Іраком (1973р.), КНДР (1957 р.), Республікою Куба (1957 р.), Монголією (1958 р.), Грецією (1981 р.), Кіпром (1984 р.), Сирійською Арабською Республікою (1984p.) та ін ${ }^{13}$.

На сьогодні уніфікація колізійних норм у сфері спадкування шляхом укладення двосторонніх міжнародних договорів про правову допомогу вважається найбільш вдалою. Проте, провівши аналіз змісту таких договорів, можемо звернути увагу як на різний підхід щодо розуміння принципу рівності у сфері спадкування, так і різний підхід у сфері колізійного регулювання питань здатності складати та скасовувати заповіт, форми заповіту та його дійсності, визначення обов'язкової частки у спадщині тощо. Також можемо спостерігати, що одні міжнародні договори про правову допомогу містять лише колізійні норми щодо форми заповіту, інші ж регулюють питання здатності складати заповіт, форми заповіту, його зміну та скасування.

Так, наприклад, можемо виділити у міжнародних договорах про правову допомогу три підходи до розуміння змісту принципу рівності у сфері спадкування, а саме: шляхом надання іноземцям таких самих прав у сфері спадкування як і власним громадянам (відбувається зрівняння у спадковій правоздатності); шляхом надання іноземцям «національного режиму», в даному випадку їх спадкова правоздатність буде визначатися, виходячи із норм національного законодавства спадкодавця чи заповідача; шляхом встановлення в міжнародному договорі певних обмежень у сфері реалізації спадкової правоздатності, тобто закріплення винятків виходячи із загального принципу рівності у спадкових відносинах ${ }^{14}$.

У сфері спадкування міжнародні договори про правову допомогу виходять із дуалістичного принципу, а саме поділу спадкового майна на рухоме та нерухоме. Щодо спадкування нерухомого майна, то міжнародні договори про правову допомогу мають однаковий підхід у сфері регулювання і виділяють колізійну прив'язку до законодавства тієї Договірної держави, на території якої знаходиться це майно. Щодо спадкування рухомого майна, то міжнародні договори про правову допомогу використовують різні колізійні критерії, наприклад: законодавство держави, громадянином якої був заповідач на момент смерті; законодавство держави, на території якої спадкодавець мав останнє місце проживання; законодавство держави, на території якої спадкодавець мав останнє місце проживання на момент смерті тощо.

Також необхідно зазначити, що двосторонні міжнародні договори у сфері надання правової допомоги залишають поза увагою правове регулювання значної кількості питань, зокрема ті з них, що пов'язані із: можливістю складати ті чи інші види заповітів; видами допустимих умов заповіту; межами розпорядження спадковим майном тощо.

Однією із найбільш вдалих спроб здійснити міжнародну уніфікацію колізійних норм у сфері спадкування на регіональному рівні є прийняття Регламенту «Рим IV». Регламент Свропейського Парламенту та Ради Європейського Союзу № 650 про компетенцію, застосовуване право, визнання і виконання рішень, прийняття і виконання нотаріальних актів з питань спадкування, а також про створення європейського свідоцтва про спадкування 15 був прийнятий 4 липня 2012 р. і набрав чинності в 2015 році. Сфера дії цього Регламенту поширюється на всі цивільно-правові аспекти спадкування майна померлих, а саме: усі форми передачі майна, прав та обов'язків з причин смерті, як добровільної передачі на підставі розпорядження на випадок смерті, так і передачі шляхом спадкування без заповіту.

Регламент встановлює, що за загальним правилом до регулювання спадкових правовідносин застосовується право держави, у якій спадкодавець мав постійне місце проживання на момент смерті. Проте заповідач має право обрати право держави, громадянином якої він був на момент такого вибору чи на момент смерті. За цим правом визначається, зокрема, здатність особи на складення заповіту.

Уніфікований акт закріплює також систему альтернативних колізійних прив'язок, що стосуються формальної дійсності заповіту. Так, згідно зі ст. 27 Регламенту, заповідальне розпорядження, складене у письмовій формі, є дійсним з точки зору його форми, якщо остання узгоджується з правом: держави, в якій було складено заповідальне розпорядження; держави, громадянином якої є спадкодавець або хоча б одна із осіб, яких стосується заповідальне розпорядження; держави, в якій спадкодавець або хоча б одна із осіб, яких стосується заповідальне розпорядження, має свій доміцилій; держави, в якій спадкодавець або хоча б одна із осіб, яких стосується заповідальне розпорядження, має своє звичайне місце проживання; держави, в якій розміщено нерухоме майно.

При цьому доміцилій, громадянство, звичайне місце проживання може визначатися або на момент складання заповідального розпорядження, або на момент (час) смерті.

Таким чином, у питаннях регулювання форми заповідальних розпоряджень положення Регламенту майже у повному обсязі кореспондуються із приписами Гаазької конвенції 1961 р. про колізії законів, які стосуються форми заповітів ${ }^{16}$.

Нововведенням Регламенту є запровадження європейського свідоцтва про спадкування. На підставі цього документа будь-який громадянин країни $Є С$ зможе підтвердити свій статус спадкоємця в іншій державі учасниці чим уникне будь-які формальності пов'язані із встановленням статусу спадкоємця на території держави місця спадкування. 
Висновки. Отже, уніфікація колізійних норм у сфері міжнародного спадкування здійснюється шляхом прийняття міжнародних договорів та вважається завершеною з моменту імплементації норм таких договорів у внутрішнє законодавство держав. На сьогодні уніфікація в галузі спадкового права є незначною і найбільш дієвою виявилася на регіональному та двосторонньому рівнях.

Провівши аналіз норм багатосторонніх міжнародних договорів у сфері міжнародного спадкування, можемо дійти висновку, що єдиний підхід лише вбачається у сфері колізійного регулювання питань спадкування нерухомого майна. Щодо колізійних норм у сфері спадкування за заповітом та у сфері права на спадкування колізійні прив'язки за змістом відрізняються.

Проаналізовано норми міжнародних договорів про правову допомогу, що закріплюють принцип рівності у спадкових правовідносинах. Звертається увага на різний підхід в міжнародних договорах про правову допомогу щодо розкриття змісту принципу рівності у спадкових відносинах, зокрема, в одних випадках, відбувається зрівняння осіб у спадковій правоздатності, в інших випадках з питань спадкової правоздатності на іноземців поширюється «національний режим», ще в інших - цей принцип розкривається шляхом встановлення в міжнародному договорі певних обмежень у сфері реалізації спадкової правоздатності.

Також звертається увага на те, що однією із найбільш вдалих спроб здійснити міжнародну уніфікацію колізійних норм у сфері спадкування є прийняття Свропейським Парламентом та Радою Свропейського Союзу Регламенту про компетенцію, застосовуване право, визнання і виконання рішень, прийняття й виконання нотаріальних актів з питань спадкування, а також про створення європейського свідоцтва про спадкування.

На сьогодні найбільш вдалою для України вважається уніфікація колізійних норм у сфері спадкування проведена на двосторонньому рівні, шляхом прийняття двосторонніх міжнародних договорів у сфері надання правової допомоги з цивільних правовідносин. Проте поза увагою двосторонніх міжнародних договорів про правову допомогу з цивільних правовідносин залишається правове регулювання значної кількість питань, зокрема, колізійне регулювання: можливості складати ті чи інші види заповітів; визначення допустимих умов заповіту; меж розпорядження спадковим майном тощо. Таким чином, незважаючи на наявність незначної кількості міжнародних договорів, потреба в уніфікації як матеріальних, так і колізійних норм у сфері міжнародного спадкування залишається.

1 Браун М.И. Введение в международное частное право. Петроград, 1915. С. 23.

2 Кармаза О.О. Міжнародне спадкове право: наук.-практ. посіб. Київ: Видавець Фурса С.Я.: КНТ, 2007. С. 200.

3 Международное частное право: учебник / под. ред. Г.К. Дмитриевой. ПБОЮЛ Гриженко Е.М., 2001. С. 175.

4 Довгерт А.С. Система приватного права та структура проекту нового Цивільного кодексу України. Українське право. 1997. № 1. С. 21.

5 Гаазька конвенція про колізії законів стосовно форми спадкових розпоряджень від 5 жовтня 1961 p. URL: http://zakon2. rada.gov.ua/laws/show/995_424

6 Вашингтонська конвенція, що передбачає уніфікований закон про міжнародний заповіт від 26 жовтня 1973 p. URL: http://zakon2.rada.gov.ua/laws/show/995_b13

7. Кармаза О.О. Спадкування у сучасному міжнародному приватному праві: автореф. дис. ... канд. юрид. наук : спец. 12.00.03. Київ. 2006. С. 13.

8 Довгерт А.С., Кисіль В.І. Міжнародне приватне право: особлива частина: підручник. Київ: Алерта, 2012. С. 362.

9 Конвенція про право, що застосовується до спадкування майна померлих осіб, прийнята у Гаазі 1 серпня 1989 p. URL: https://assets.hcch.net/docs/5af01fa4-c81f-4e99-b214-64421135069f.pdf

${ }^{10}$ Кисіль В. Спадкові відносини в сучасному міжнародному приватному праві. Право Украӥни. 2013. № 7. С. 167.

11 Конвенція про правові відносини і правову допомогу у цивільних, сімейних та кримінальних справах від 22 січня 1993 p. URL: http://zakon3.rada.gov.ua/laws/show/997_009/print1444315331426685

12 Абраменков М.С., Чугунов П.В. Наследственное право: учебник для магистров / отв. ред. В.А. Белов. Москва: Изд-во Юрайт, 2013. С. 416.

13 Довгерт А.С., Кисіль В.І. Міжнародне приватне право: особлива частина: підручник. Київ: Алерта, 2013. С. 79-80.

14 Михайлів М.О. Міжнародні договори України про правову допомогу в цивільних справах як джерело правового регулювання спадкування за заповітом в міжнародному приватному праві. Підприємнищтво, господарство і право. 2018 . № 10. C. 231.

15 Регламент Свропейського Парламенту та Ради Європейського Союзу про компетенцію, застосовуване право, визнання і виконання рішень, прийняття і виконання нотаріальних актів 3 питань спадкування, а також про створення європейського свідоцтва про спадкування від 4 липня 2012 р. № 650/2012. URL: http://eur-lex.europa.eu/LexUriServ/LexUriServ.do?uri=OJ:L:2012: 201:0107:0134:EN:PDF

16 Слабошпицька У.О. Система колізійних норм Риму IV: основні положення Регламенту (ЄС) № 650/2012. Науковий вісник УжНУ. Серія «Право». 2015. № 34. Т. 1. С. 103.

\section{References:}

Braun, M.Y. (1915) Vvedenye v mezhdunarodnoe chastnoe pravo. Ph. [in Ukrainian].

Karmaza, O.O. (2007) Mizhnarodne spadkove pravo: Naukovo-praktychnyy posibnyk. K.: Vydavets' Fursa S.Ya.: KNT [in Ukrainian].

Mezhdunarodnoe chastnoe pravo: Uchebnyk. Pod.red. G.K. Dmytryevoy. PBOYUL Hryzhenko E.M., 2001 [in Ukrainian].

Dovhert, A.S. (1997) Systema pryvatnoho prava ta struktura proektu novoho Tsyvil'noho kodeksu Ukrayiny. Ukrayins'ke pravo. 1 [in Ukrainian]. 


\section{Проблеми цивільного, господарського, трудового права та права соціального забезпечення}

Haaz'ka konventsiya pro koliziyi zakoniv stosovno formy spadkovykh rozporyadzhen' vid 5 zhovtnya 1961 roku URL: http://zakon2. rada.gov.ua/laws/show/995_424 [in Ukrainian].

Vashynhtons'ka konventsiya, shcho peredbachaye unifikovanyy zakon pro mizhnarodnyy zapovit vid 26 zhovtnya 1973 roku URL: http://zakon2.rada.gov.ua/laws/show/995 b13 [in Ukrainian].

Karmaza, O.O. (2006) Spadkuvannya u suchasnomu mizhnarodnomu pryvatnomu pravi : avtoref. dys. ... kand. yur. nauk : spets.

12.00.03 «Tsyvil'ne pravo i tsyvil'nyy protses; simeyne pravo; mizhnarodne pryvatne pravo». Kyyiv [in Ukrainian].

Dovhert, A.S. (2012) Mizhnarodne pryvatne pravo: osoblyva chastyna: pidruchnyk. Kyyiv: Alerta [in Ukrainian].

Konventsiya pro pravo, shcho zastosovuyet'sya do spadkuvannya mayna pomerlykh osib, pryynyata u Haazi 1 serpnya $1989 \mathrm{r}$.

URL: https://assets.hcch.net/docs/5af01fa4-c81f-4e99-b214-64421135069f.pdf [in Ukrainian].

Kysil', V. (2013) Spadkovi vidnosyny v suchasnomu mizhnarodnomu pryvatnomu pravi. Pravo Ukrayiny. 7 [in Ukrainian].

Konventsiya pro pravovi vidnosyny i pravovu dopomohu u tsyvil'nykh, simeynykh ta kryminal'nykh spravakh vid 22 sichnya

1993 roku. URL: http://zakon3.rada.gov.ua/laws/show/997_009/print1444315331426685 [in Ukrainian].

Abramenkov, M.S. (2013) Nasledstvennoe pravo: uchenyk dlya mahystrov. M.: Yzdatel'stvo Yurayt [in Ukrainian].

Dovhert, A.S. (2013) Mizhnarodne pryvatne pravo: osoblyva chastyna: pidruchnyk. Kyyiv: Alerta [in Ukrainian].

Mykhayliv, M.O. (2018) Mizhnarodni dohovory Ukrayiny pro pravovu dopomohu v tsyvil'nykh spravakh yak dzherelo pravovoho rehulyuvannya spadkuvannya za zapovitom v mizhnarodnomu pryvatnomu pravi. Pidpryyemnytstvo, hospodarstvo i pravo. 10 [in Ukrainian].

Rehlament Yevropeys'koho Parlamentu ta Rady Yevropeys'koho Soyuzu pro kompetentsiyu, zastosovuvane pravo, vyznannya i vykonannya rishen', pryynyattya i vykonannya notarial'nykh aktiv z pytan' spadkuvannya, a takozh pro stvorennya yevropeys'koho svidotstva pro spadkuvannya vid 4 lypnya 2012 roku№ 650/2012 URL: http://eur-lex.europa.eu/LexUriServ/LexUriServ.do?uri=OJ:L: 2012:201:0107:0134:EN:PDF [in Ukrainian].

Slaboshpyts'ka, U.O. (2015) Systema koliziynykh norm Rymu IV: osnovni polozhennya Rehlamentu (YES) № 650/2012. Naukovyy visnyk UzhNU. Seriya «Pravo». 34 [in Ukrainian].

\section{Резюме}

Михайлів М.O. Уніфікація колізійних норм у сфері спадкових відносин.

У статті досліджуються питання, пов'язані із проблемами уніфікації колізійних норм у сфері міжнародних спадкових відносин. Проаналізовані підходи до поняття та правової природи уніфікації норм в міжнародному приватному праві. Висвітлено актуальні проблеми колізійного регулювання спадкових відносин за допомогою багатосторонніх міжнародних договорів. Особливу увагу приділено проблемам колізійного регулювання питань спадкування у міжнародних договорах про правову допомогу з цивільних правовідносин. 3 метою належного регулювання спадкових відносин з іноземним елементом запропоновано і надалі продовжувати проводити уніфікацію колізійних норм у сфері спадкування.

Ключові слова: уніфікація, спадкування, спадкування в міжнародному приватному праві, колізійні норми у сфері спадкових відносин.

\section{Резюме}

Мыхайлив М.E. Унификация коллизионных норм в сфере наследственных отношений.

В статье исследуются вопросы, связанные с проблемами унификации коллизионных норм в сфере международных наследственных отношений. Проанализированы подходы к понятию и правовой природе унификации норм в международном частном праве. Освещены актуальные проблемы коллизионного регулирования наследственных отношений с помощью многосторонних международных договоров. Особое внимание уделено проблемам коллизионного регулирования вопросов наследования в международных договорах о правовой помощи по гражданским правоотношениям. С целью надлежащего регулирования наследственных отношений с иностранным элементом предложено и дальше продолжать проводить унификацию коллизионных норм в сфере наследования.

Ключевые слова: унификация, наследование, наследование в международном частном праве, коллизионные нормы в сфере наследственных отношений.

\section{Summary}

Mariya Mykhailiv. Unification of Conflict Rules in the Field of Hereditary Relations.

The only and most effective way of unification of norms in the field of international hereditary relations is the adoption of international treaties nowadays. The norms of international treaties are the effective instrument that helps to eliminate the contradictions between the material norms and conflict rules of states in this field.

Issues of unification of norms in the field of hereditary relations in private international law have been studied by a set of Ukrainian and foreign researches, such as: Brawn M.I., Galushchenko H.V., Hetman-Pavlova I.H, Vilkova N.H., Dmytriieva H. K., Dovgert A. S., Karmaza O.O., Kysil V. I., Lunts L.A., Medvediev I. H., Orlova N.V., Rubanov A.A., Stepaniuk A.A., Tolstykh V.L., Fursa Y.I., Fursa S.A., Khachaturian A.H. etc. However, there are still many issues that need research and are relevant.

Nowadays, international unification in the field of inheritance is insignificant. Only a few multilateral international treaties have been adopted at the international level, including: Convention of 5 October 1961 on the Conflicts of Laws Relating to the Form of Testamentary Dispositions (Hague); Convention Providing a Uniform Law on the Form of an International Will (Washington, D.C., October 26, 1973); Convention of 1 August 1989 on the Law Applicable to Succession to the Estates of Deceased Persons (Hague); Convention of 2 October 1973 Concerning the International Administration of the Estates of Deceased Persons (Hague).

Having analyzed the norms of multilateral international treaties in the field of international inheritance, we can conclude that the unified approach exists only in the area of conflict regulation of issues of inheritance of real estate. As for conflict rules in the field of inheritance by will and in the field of right to inheritance, conflict rules differ in their content.

The attention is also drawn to the fact that one of the most successful attempts to achieve the international unification of conflict rules in the field of inheritance is the adoption by the European Parliament and the Council of the European Union of the Regulation 
Цувіна T.A. «Суд, встановлений законом» як елемент права на справедливий судовий розгляд у цивільному...

on jurisdiction, applicable law, recognition and enforcement of decisions and acceptance and enforcement of authentic instruments in matters of succession and on the creation of a European Certificate of Succession.

For Ukraine, the most successful is the unification of conflict rules in the field of inheritance, conducted at the bilateral level, through the adoption of bilateral international treaties in the field of providing legal assistance in civil relations. Having analyzed the content of such treaties, we can draw attention to both the different approaches to understanding the principle of equality in the field of inheritance, and the different approaches in the area of conflict regulation of the ability to make and cancel a will, the form of a will and its validity, the determination of a mandatory share in the inheritance, etc. We can also observe that some international legal aid treaties include only conflict rules regarding the form of a will, and the other treaties regulate the issue of the ability to make a will, the form of a will, its amendment and cancellation.

In the area of inheritance, international legal aid treaties are based on a dualistic principle, namely the division of hereditary property into movable and immovable property. With respect to the inheritance of immovable property, international legal aid treaties take single approach in regulation and determine the connecting factor with the law of the state in the territory of which the property is situated. With regard to the inheritance of movable property, international legal aid treaties use different connecting criteria, for example: the law of the state of which the testator was a national at the time of death; the law of the state in which territory the testator had his last residence, etc.

It should also be noted that bilateral international agreements on legal aid for civil relations, omit a large number of legal issues, in particular conflict regulation of: the ability to make certain types of wills; determination of the permissible terms of a will; the boundaries of the disposal of hereditary property, etc. Thus, despite the presence of a set of international treaties, the need for unification of both material and conflict rules in the field of international inheritance remains.

Key words: unification, hereditary, hereditary in international private law, conflict rules in the field of hereditary relations.

DOI: 10.36695/2219-5521.2.2019.24

УДК 347.9

\section{T.А. ЦУВІНА}

Тетяна Андріївна Цувіна, кандидат юридичних наук, доцент Національного юридичного університету імені Ярослава Мудрого*

ORCID 0000-0002-5351-1475

\section{«СУД, ВСТАНОВЛЕНИЙ ЗАКОНОМ» ЯК ЕЛЕМЕНТ ПРАВА НА СПРАВЕДЛИВИЙ СУДОВИЙ РОЗГЛЯД У ЦИВІЛЬНОМУ СУДОЧИНСТВІ}

Постановка проблеми. Провідне значення для цивільного судочинства має п. 1 ст. 6 Конвенції про захист прав людини та основоположних свобод (далі - ЄКПЛ), відповідно до якого кожний має право на справедливий і публічний розгляд його справи упродовж розумного строку незалежним і безстороннім судом, встановленим законом, який вирішить спір щодо його прав та обов'язків цивільного характеру. Одним із елементів права на справедливий судовий розгляд, що текстуально закріплений у цій статті, $€$ вимога, згідно з якою суд має бути «встановлений законом». У зв'язку із зазначеним актуальності набуває тлумачення зазначеного поняття у практиці Європейського суду з прав людини (далі - ЄСПЛ) з метою приведення національного законодавства у відповідність до міжнародних стандартів цивільного судочинства.

Аналіз останніх досліджень і публікацій. Окремим аспектам вивчення інституційних вимог до суду у демократичному суспільстві у світлі п. 1 ст. 6 ЄКПЛ були присвячені праці Л. Вільдхабера, О.В. Колісник, В.В. Комарова, М. Куїджера, Т.М. Нешатаєвої, Н.Ю. Сакари, В.В. Сердюка, Л.В. Туманової, О.З. ХотинськоїНор та ін. Разом із тим системного аналізу вимоги «суд, встановлений законом» як елемента права на справедливий судовий розгляд у літературі не проводилося.

Метою статті $\epsilon$ дослідження еволюційного тлумачення вимоги «суд, встановлений законом» як елемента права на справедливий судовий розгляд, передбаченого п. 1 ст. 6 ЄКПЛ, у практиці ЄСПЛ.

Виклад основного матеріалу. ЄСПЛ неодноразово підкреслював, що відповідно до п. 1 ст. 6 ЄКПЛ суд має бути «встановлений законом», що відбиває принцип верховенства права, який є невід'ємною складовою системи захисту, встановленої СКПЛ та Протоколами до неї1. Зазначена вимога тісно пов'язана 3 іншими важливими вимогами ст. 6 ЄКПЛ, а саме незалежністю та неупередженістю суду, які у сукупності відбивають той рівень довіри, який суди мають викликати в суспільстві².

Передусім зазначена вимога має тлумачитися буквально з точки зору наявності правової основи існування суду, адже метою іiї закріплення у п. 1 ст. 6 СКПЛ необхідність забезпечення того, щоб судова система у демократичному суспільстві не залежала від розсуду органів виконавчої влади, а натомість регулювалася законом, ухваленим парламентом³. Аналогічно і в державах, де право є кодифікованим, організація судової системи не може бути віддана до дискреційних повноважень органів судової влади, проте це не означає, що

() Т.А. Цувіна, 2019

${ }^{*}$ Tetiana Tsuvina, Ph.D. in Law, Associate professor of Yaroslav Mudryi National Law University 